\title{
Improved greenhouse cucumber production under deficit water and fertilization in Northern China
}

\author{
Shaikh Abdullah Al Mamun Hossain ${ }^{1,2}$, Lixue Wang ${ }^{1 *}$, Haisheng Liu ${ }^{1}$ \\ (1. College of Water Conservancy, Shenyang Agricultural University, Shenyang 110866, Liaoning, China; \\ 2. Department of Agricultural Engineering, Patuakhali Science and Technology University, Dumki, Patuakhali 8602, Bangladesh)
}

\begin{abstract}
The objective of this study was to investigate the effects of different water and fertilizer applications on biomass, yield and fruit physical quality of greenhouse cucumber under drip irrigation. The experiment was conducted at Water Conservancy Research Institute, Shenbei District, Shenyang, Northern China during February-July, 2016. Nine treatments were used in randomized block design consisted of three levels of water field capacity (FC) and urea-potash (N-K) fertilizer combinations: $\mathrm{W}_{1}$ (65\% of FC), $\mathrm{W}_{2}$ (75\% of FC), $\mathrm{W}_{3}\left(85 \%\right.$ of FC) and $\mathrm{N}_{1}-\mathrm{K}_{1}\left(285-305 \mathrm{~kg} / \mathrm{hm}^{2}\right), \mathrm{N}_{2}-\mathrm{K}_{2}\left(420-435 \mathrm{~kg} / \mathrm{hm}^{2}\right)$, $\mathrm{N}_{3}-\mathrm{K}_{3}\left(530-565 \mathrm{~kg} / \mathrm{hm}^{2}\right)$. Local farmers' conventional application of water (100\%) and fertilizer (NPK) was considered as check (CK) for comparison. Data obtained was analyzed (ANOVA) to check the significant effect of treatments. The results revealed that, treatment $\mathrm{W}_{3} \mathrm{~N}_{2} \mathrm{~K}_{1}$ obtained highest cucumber yield of $129.99 \mathrm{t} / \mathrm{hm}^{2}$, while $\mathrm{W}_{1} \mathrm{~N}_{1} \mathrm{~K}_{1}$ recorded the lowest yield $\left(113.29 \mathrm{t} / \mathrm{hm}^{2}\right)$, in which total amount of seasonal water applied ranges from $85.3 \mathrm{~mm}$ to $172.36 \mathrm{~mm}$. The highest yield was obtained $0.5 \%$ greater than the CK yield $\left(129.35 \mathrm{t} / \mathrm{hm}^{2}\right)$. The water and fertilizer application was significantly $(p<0.001)$ influenced on cucumber yield. Moreover, the influence of water application was significantly $(0.01<p<0.05)$ on both green and dry biomass accumulation except green leaf weight and fruit physical quality. It was also revealed that, the highest green biomass accumulation $(572.4 \mathrm{~g} /$ plant $)$ and fruit diameter $(27.92 \mathrm{~mm})$ with treatment $\mathrm{W}_{3} \mathrm{~N}_{2} \mathrm{~K}_{1}$ have significant influence on improved yield. In conclusion, the improved cucumber yield indicated $15 \%$ deficit water tolerance, in which average seasonal yield response factor $\left(K_{y}\right)$ was calculated as 0.22 . Therefore, the treatment $\mathrm{W}_{3} \mathrm{~N}_{2} \mathrm{~K}_{1}$ could successfully be used to minimize water and fertilizer application for improving greenhouse cucumber yield.
\end{abstract}

Keywords: cucumber, drip irrigation, fertilizer, greenhouse, yield

DOI: $10.25165 /$ j.ijabe.20181104.3566

Citation: Mamun Hossain S A, Wang L X, Liu H S. Improved greenhouse cucumber production under deficit water and fertilization in Northern China. Int J Agric \& Biol Eng, 2018; 11(4): 58-64.

\section{Introduction}

Optimum utilization of resources for maximum quality output is now a target in agricultural production system. The food and fiber demand in South Asian countries is projected to double in 30 years ${ }^{[1]}$. As the production land is no more increasing, the expanding population would certainly face hunger with inadequate food production in future. Using technological knowledge, drip irrigation with fertilization can achieve improved yield due to adequate soil-water movement by reducing salinity and can improve crop root zone environment as well ${ }^{[2]}$. Drip water distributions were characterized delimited root system requiring repeated nutrient supply, satisfied by irrigation with fertilization at specific root zone area, which will avoid nutrient leaching and optimize yield $^{[3]}$. This affirmative environment for root and crop growth also improved the efficiency of irrigation and fertilizer application in greenhouse cucumber production. Therefore, it is

\section{Received date: 2017-06-16 Accepted date: 2018-03-16}

Biographies: Shaikh Abdullah Al Mamun Hossain, PhD, Associate Professor, research interests: irrigation, agricultural water saving practices, river and water resources management, Email: mamagepstu@yahoo.com; Lixue Wang, PhD, Professor, research interests: water resources and agricultural water utilization, Email: wlx1964@163.com; Haisheng Liu, PhD, Lecturer, research interests: irrigation equipment and water environment, Email: liuthjsheng@126.com.

*Corresponding author: Lixue Wang, $\mathrm{PhD}$, Professor, research interests: water resources and agricultural water utilization. Address: College of Water Conservancy, Shenyang Agricultural University, Shenyang 110866, Liaoning, China. Tel: +86-24-88487134, Fax:+86-24-88417416, Email: wlx1964@163.com. immensely important to establish a greenhouse cucumber production system under an appropriate combination of drip water and fertilization, which can obtain satisfactory marketable yield. Simultaneously, it needs to formulate an irrigation scheduling that can balance water saving and yield improving.

The cucumber (Cucumis sativus L.) is a popular vegetable and is considered important as a dietary due to its economic value. Globally, cucumber is attaining importance and has a leading production of about 40 million t per year ${ }^{[4]}$. Cucumber production in solar greenhouse under drip irrigation in North and Northwest regions of China is now rapidly developing to improve production as well as famer's income due to long winter with heavy snow, where water scarcity has become a serious problem ${ }^{[5-8]}$. It is also becoming extensively popular and suitable by maintaining microclimate inside greenhouse which leads to improved returns ${ }^{[9]}$. To achieve satisfactory yield, cucumber needs to be produced under favorable climatic condition with relatively high soil moisture and temperature ${ }^{[10]}$. Solar greenhouse is a suitable place to favorably control the climate for higher cucumber production in Northern China. The irrigation schedule in greenhouse cucumber production in this area was managed by farmers to get high yield, which may lead to huge water losses and poor quality fruits ${ }^{[5]}$. Nevertheless, maximum yield with poor quality fruit does not carry better earnings due to low market price and high cost of irrigation. Many authors reported their research on the evaluation of yield and irrigation efficiency in greenhouse cucumber under drip irrigation with plastic mulching ${ }^{[10]}$, with scheduling based on pan evaporation $^{[7,9,11]}$, and with different soil moisture content ${ }^{[12]}$, 
evapotranspiration $^{[13]}$ and soil moisture tension ${ }^{[14]}$. However, scheduling on greenhouse cucumber production based on water field capacity has received very little attention.

Moreover, several studies indicated the yield and quality of greenhouse cucumber under drip irrigation with only nitrogen ${ }^{[15]}$, or using same level of NPK $(20: 20: 20)$ fertilization ${ }^{[16]}$. Consequently, without appropriate combination of fertilizer, yield did not meet the desired output ${ }^{[8]}$. In reaction to various challenges facing the irrigated agriculture like water scarcity, increasing population and demand, attention should be focused on the efficient use of water with other input resources as well. This can be succeeded by using improved methods of irrigation management practices ${ }^{[10]}$. Therefore, certain deficit water application and proper fertilizer input with careful management for receiving increased marketable cucumber yield can greatly contribute to water saving. This paper reported the effects of different levels of drip water field capacity and urea-potash fertilizer combined application on greenhouse cucumber biomass, yield and fruit physical quality in Northern China.

\section{Materials and methods}

\subsection{Experimental location and condition}

The experiment was conducted in a greenhouse during February-July, 2016 at the research institute of Liaoning Water Conservancy, Shenyang, Liaoning Province, China. The greenhouse is $86 \mathrm{~m}$ long, $9.94 \mathrm{~m}$ wide and $4.5 \mathrm{~m}$ high in a single-slope roof structure covered by $500 \mu \mathrm{m}$ transparent polyethylene film without heating and ventilation system. The research station is situated in $123^{\circ} 31^{\prime} \mathrm{E}$ and $42^{\circ} 09^{\prime} \mathrm{N}$ at Shenbei District, Northern Shenyang, capital city of Liaoning Province. According to the weather record of this research station, the area has a long winter (Sep-April), in which minimum temperature was less than $-24^{\circ} \mathrm{C}$; and a very short rainy summer (July-August) and a short windy spring. The annual mean temperature was recorded as $6.63^{\circ} \mathrm{C}$. The annual precipitation and the relative humidity of this area were recorded as $507.23 \mathrm{~mm}$ and an average of $67.43 \%$ respectively. The soil properties in the greenhouse were clay-loamy with $24 \%$ field capacity and $1.65 \mathrm{~g} / \mathrm{cm}^{3}$ bulk density. The average temperature and the relative humidity in greenhouse during cropping season were $21.4^{\circ} \mathrm{C}$ and $68.8 \%$, respectively.
The air temperature and the relative humidity fluctuation recorded by automatic weather station inside greenhouse during cropping season are depicted in Figure 1.

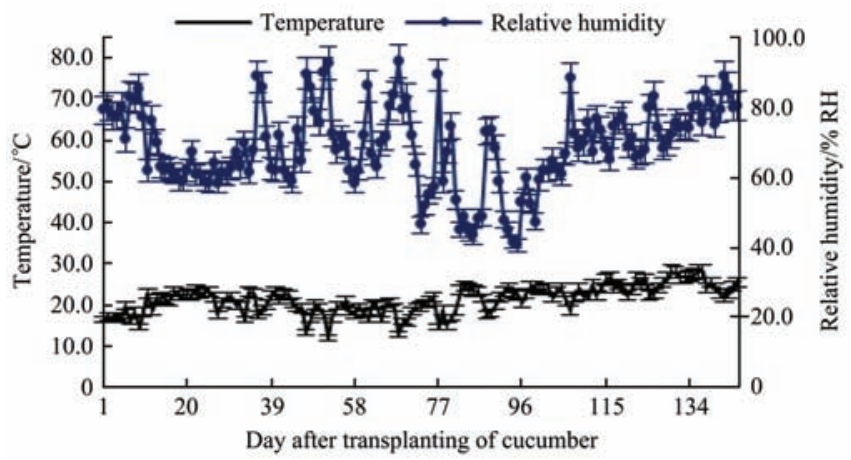

Figure 1 Daily average temperature and relative humidity status during cropping season (error bar represents $\pm 5 \%$ of values)

\subsection{Treatment design}

Nine treatments were designed with three levels of water, urea $(\mathrm{N})$ and potash $(\mathrm{K})$ fertilizer with local farmer's conventional application of water $(100 \%)$ and fertilizer (NPK) termed as Control (CK). The randomized block design was employed with three irrigation amount based on water field capacity (FC): $\mathrm{W}_{1}(65 \%)$, $\mathrm{W}_{2}(75 \%) \& \mathrm{~W}_{3}(85 \%)$; three urea application amount: $\mathrm{N}_{1}$ $\left(285 \mathrm{~kg} / \mathrm{hm}^{2}\right), \mathrm{N}_{2}\left(420 \mathrm{~kg} / \mathrm{hm}^{2}\right) \& \mathrm{~N}_{3}\left(530 \mathrm{~kg} / \mathrm{hm}^{2}\right)$ and three potash application amount: $\mathrm{K}_{1}\left(305 \mathrm{~kg} / \mathrm{hm}^{2}\right), \mathrm{K}_{2}\left(435 \mathrm{~kg} / \mathrm{hm}^{2}\right) \& \mathrm{~K}_{3}$ $\left(565 \mathrm{~kg} / \mathrm{hm}^{2}\right)$. Urea has a $\mathrm{N}$ content of 46 , and potash has a $\mathrm{N}$ content of $13.5 \%$ and $\mathrm{K}$ content of $46 \%$. The potassium dihydrogen phosphate $\left(\mathrm{KH}_{2} \mathrm{PO}_{4}\right)$ was applied universally at $325 \mathrm{~kg} / \mathrm{hm}^{2}$ in all treatment, in which Phosphate $(\mathrm{P})$ content is $52 \%$. The NPK fertilizer (N: 250, $\mathrm{P}_{2} \mathrm{O}_{5}: 80$ and $\mathrm{K}_{2} \mathrm{O}: 350 \mathrm{~kg} / \mathrm{hm}^{2}$ ) was applied in $\mathrm{CK}$ as noticed by Qi et al. ${ }^{[17]}$. Each treatment plot area was $52.5 \mathrm{~m}^{2}$ including five sub-plots of $7 \mathrm{~m}$ long and $1.5 \mathrm{~m}$ wide. All sub-plots were covered by thin black plastic mulch to confine the evaporation loss. The details of experimental layout are depicted in Figure 2. The drip irrigation system was installed before transplanting cucumber seedling including control box, water pump, water meter, solenoid valve etc. developed by 'Witu Technology' China.

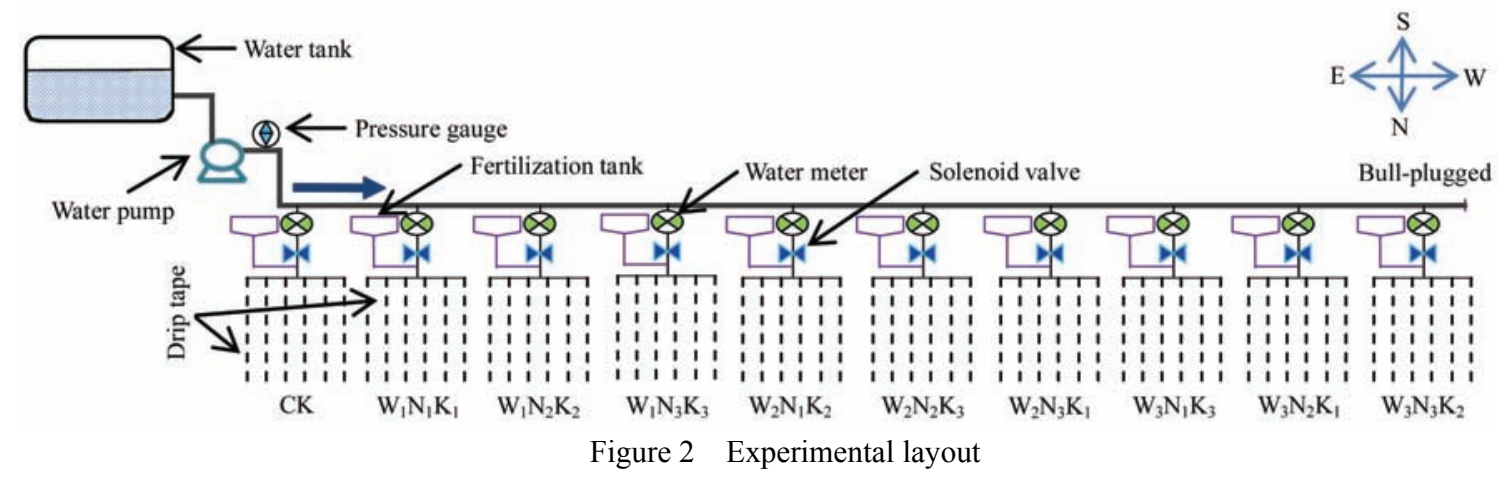

The PVC lateral pipe with $32 \mathrm{~mm}$ outer diameter and $25 \mathrm{~mm}$ inner diameter was installed for water delivery from pump to water dripping tape. Two $(0.2 \mathrm{~mm}$ thick $)$ polyethylene type water-dripping tapes with $16 \mathrm{~mm}$ outer diameter were laid on the sub-plot center ('Run-Hua Irrigation' brand, China). The dripping emitter spacing was designed as $0.3 \mathrm{~m}$ in which dripper head flow capacity was $1.38 \mathrm{~L} / \mathrm{h}$ with operating pressure $0.1 \mathrm{MPa}$.

\subsection{Agronomic management}

The cucumber (local variety "Maria") seedlings were transplanted at 26 February, 2016 using two rows in each sub-plot; in which $1.2 \mathrm{~m}$ bed width and $0.15 \mathrm{~m}$ height as shown in Figure 3. The two row spaced layout of cucumber was planted at $0.6 \mathrm{~m}$ in which dripping tape was placed at $0.3 \mathrm{~m}$ apart from each plant. The plant to plant distance in single row was maintained $0.4 \mathrm{~m}$. During tillage and land preparation well-rotted compost (mixture of vegetation and poultry waste) $22.5 \mathrm{~m}^{3} / \mathrm{hm}^{2}$ and NPK $(19 \%$ Nitrogen, $6 \%$ Phosphate and 20\% Potash) $750 \mathrm{~kg} / \mathrm{hm}^{2}$ were applied as base fertilizer. According to experimental design, the fertilizer 
mixed with irrigation water was applied at the end of the development stage of cucumber and provided in six times with an equal interval until the last harvesting period, and same amount of fertilizer was allocated in each application. The cucumber plants were trained vertically only on main branch by rope. Others activities, plastic mulching, pruning, pest control etc. were universally managed for all treatments.

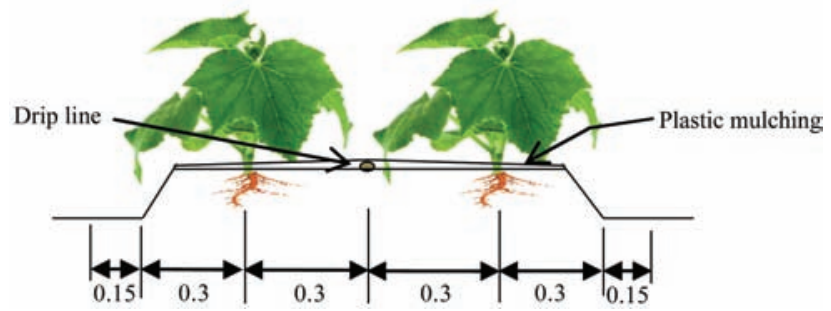

Figure 3 Schematic figure of cucumber sub-plot design (unit, $\mathrm{m}$ )

\subsection{Crop water estimation and management}

The irrigation was scheduled based on soil moisture content (SMC) for all treatments. The SMC was checked at $10-20 \mathrm{~cm}$ soil layer depth from each treatment as plant roots system was mostly developed within this layer ${ }^{[18]}$. The Gravimetric method was used to determine the SMC (\%). After 24 hours of each irrigation, soil samples were collected for determining SMC (\%) until it dropped at designed level. Beside this, SMC was also monitored for calibrating with gravimetric method data using TRIME-IPH digital instrument, Canada. Before transplanting of seedling, we have burred four round shape TRIME-tube up to $60 \mathrm{~cm}$ soil depth at four locations $\left(\mathrm{W}_{1}, \mathrm{~W}_{2}, \mathrm{~W}_{3}\right.$ and $\left.\mathrm{CK}\right)$ of each treatment group. The irrigation scheduled was started when the SMC equal equaled or dropped at design level amounting the volumetric water $(\mathrm{mm})$ estimated by the Equation $(1)^{[19]}$. Similar method has been used by Israelsan and Hansen ${ }^{[20]}$, Mamun Hossain et al. ${ }^{[21]}$ and followed by Hamza and Almasraf ${ }^{[12]}$.

$$
m=0.1\left(\beta_{f}-\beta_{0}\right) H \rho \gamma
$$

where, $m$ is crop water required depth, $\mathrm{mm} ; \beta_{f}$ is soil moisture content in field capacity, $\% ; \beta_{0}$ is measured soil moisture content, $\% ; H$ is soil layer depth, $\mathrm{m} ; \gamma$ is soil bulk density, $\mathrm{t} / \mathrm{m}^{3} ; \rho$ is wetting parameter, \%. For vegetables in drip irrigation system, $\rho$ values vary from $60 \%-90 \%$. The amount of volumetric water requirement $\left(\mathrm{m}^{3}\right)$ was estimated using the treatment area that can easily readable in water meter. Primarily, cucumber seedlings were irrigated by three levels of water at $0.5 \mathrm{~m}^{3}(10 \mathrm{~mm}), 0.8 \mathrm{~m}^{3}$ $(15 \mathrm{~mm})$ and $1.0 \mathrm{~m}^{3}(20 \mathrm{~mm})$ at $4 \mathrm{~d}$ interval equally each treatment respectively. At the beginning of development stage, irrigation was scheduled by monitoring SMC according to treatment design.

The total amount of seasonal water application was considered as actual evapotranspiration $\left(E T_{a}\right)$ on the basis of water balance calculation method. In greenhouse condition there was no rainfall nor runoff due to drip control irrigation; deep percolation was considered as negligible that was checked by TRIME-IPH digital instrument. Also the variation of gravimetric moisture content after $24 \mathrm{~h}$ of irrigation was found very insignificant.

\subsection{Harvesting of biomass and yield}

The cucumber plants (100 days after transplanting) were harvested randomly in two replications from each treatment with leaves separated from stems. After measuring green weight (separately leaves and stems) in gram (g) per plant, plant parts were dried into sunlight and then drought into oven at $80^{\circ} \mathrm{C}$ for $24 \mathrm{~h}$ to estimate the dry weight $(\mathrm{g})$. The cucumber fruits harvesting was started from $35 \mathrm{~d}$ after transplanting. Fruits were harvested from one $\mathrm{m}^{2}$ selected area in three replications in each treatment. Cucumber were collected in 3-5 d interval and weighted the marketable fruits using electronic balance and expressed in $\mathrm{kg} / \mathrm{m}^{2}$ using Equation (2) as follows:

$$
\text { Yield }=\frac{\text { Total weight of cucumber }(\mathrm{kg})}{\text { Total area of harvested cucumber }\left(\mathrm{m}^{2}\right)}
$$

After final harvest, at $147 \mathrm{~d}$ after transplanting all data were accumulated into $\mathrm{t} / \mathrm{hm}^{2}$.

\subsection{Calculation of water use efficiency (WUE)}

The obtained yield to amount of volumetric water application is expressed as water use efficiency (WUE, $\mathrm{kg} / \mathrm{m}^{3}$ ). The WUE was calculated using the Equation (3) followed by various researches ${ }^{[5,14,18,22-23]}$ as follows:

$$
W U E=\frac{Y}{m}
$$

where, WUE is water use efficiency, $\mathrm{kg} / \mathrm{m}^{3} ; Y$ is fruits yield, $\mathrm{kg} / \mathrm{hm}^{2}$; and $m$ is crop water consumption, $\mathrm{m}^{3} / \mathrm{hm}^{2}$.

The relation between crop yield and seasonal water used $\left(E T_{a}\right)$ is termed as water production function (WPF), which indicates the relative reduction of yield is correlated linearly to the corresponding relative decrease in water application with a slope called yield response factor $\left(K_{y}\right)^{[24]}$. Specifically, the WPF was calculated using the Equation (4) as follows ${ }^{[25,26]}$ :

$$
\left[1-\left(\frac{Y_{a}}{Y_{m}}\right)\right]=K_{y}\left[1-\left(\frac{E T_{a}}{E T_{m}}\right)\right]
$$

where, $Y_{a}$ and $Y_{m}$ are actual and maximum (obtained from $\mathrm{W}_{3}$ group treatment) yield $\left(\mathrm{t} / \mathrm{hm}^{2}\right)$ respectively; $E T_{a}$ and $E T_{m}$ are actual and maximum (obtained from full irrigation, $\mathrm{CK}$ ) seasonal water applied $\left(\mathrm{m}^{3} / \mathrm{hm}^{2}\right)$ respectively.

The cucumber fruit physical quality, such asfruit weight (FW), fruit length (FL) and fruit diameter (FD), was measured during harvesting period following different research ${ }^{[9,11]}$. Fruits were collected randomly in three replications by selecting three plants in each treatment at $122 \mathrm{~d}, 127 \mathrm{~d}$ and $134 \mathrm{~d}$ after transplanting. Electronic balance, measuring tape and Vernier caliper were used to determine the fruit weight $(\mathrm{g})$, length $(\mathrm{cm})$, and diameter $(\mathrm{mm})$ respectively.

\subsection{Data analysis}

For assessing the effect of irrigation and fertilizer on cucumber biomass, yield and fruit physical quality, data were statistically analyzed by one-way ANOVA. Differences between means were calculated for significance test by Tukey's-b test. All statistical processes were accomplished by IBM-SPSS 19.0 version software and also using MS excel.

\section{Results and Discussion}

\subsection{Effects of treatments on biomass accumulation}

The effects of irrigation and fertilizer combined application on cucumber biomass accumulation (green $\&$ dry) are given in Table 1. The cucumber leaf, stem and total biomass accumulation are also illustrated in Figures $4 \mathrm{a}$ and $4 \mathrm{~b}$. The highest value of total green biomass accumulation was $572.4 \mathrm{~g} /$ plant which was achieved in treatment $\mathrm{W}_{3} \mathrm{~N}_{2} \mathrm{~K}_{1}$, while the lowest value was $459.0 \mathrm{~g} / \mathrm{plant}$ achieved in $\mathrm{W}_{1} \mathrm{~N}_{2} \mathrm{~K}_{2}$. The highest value is $20 \%$ and $14 \%$ greater than lowest value and CK value (494.8 g/plant) respectively. Meanwhile, the highest value of total dry biomass was obtained in treatment $\mathrm{W}_{3} \mathrm{~N}_{3} \mathrm{~K}_{2}(52.9 \mathrm{~g} / \mathrm{plant})$, which was $28 \%$ and $1 \%$ greater than the lowest value obtained in $\mathrm{W}_{1} \mathrm{~N}_{2} \mathrm{~K}_{2}$ (37.9 g/plant) and CK value $(52.5 \mathrm{~g} /$ plant $)$ respectively. Beyaert et al. ${ }^{[27]}$ reported three 
consecutive years of total dry biomass accumulation in field grown cucumber with the value of $2529.5 \mathrm{~kg} / \mathrm{hm}^{2}, 3475.2 \mathrm{~kg} / \mathrm{hm}^{2}$ and $2541.4 \mathrm{~kg} / \mathrm{hm}^{2}$ using surface drip irrigation. Ghehsareh et al. ${ }^{[28]}$ reported the highest wet and dry biomass accumulation value of greenhouse cucumber of $550.2 \mathrm{~g} /$ plant and $88.44 \mathrm{~g} / \mathrm{plant}$, which produced highest yield growing in palm culture substrates. Result in this study is consisted with the previous reports, that the highest green biomass accumulation was related to the treatment of highest yield production.

The statistical analysis showed that, water application for all treatments significantly $(p<0.05)$ influenced individual and total green biomass accumulation except green leaf weight, while water had more significant effect $(p<0.01)$ on total dry biomass accumulation (Table 1). Results also revealed that based on Tukey's-b test, various treatments showed no significant difference on the mean values of individual and total green and dry biomass accumulation, The urea application does not significantly influence green and dry biomass accumulation except green leaf $(p<0.01)$ and dry stem weight $(p<0.05)$, while potash application has significant, $(p<0.05)$ effect on only total green and dry biomass accumulation.

Table 1 Effects of treatments on biomass accumulation of cucumber

\begin{tabular}{|c|c|c|c|c|c|c|}
\hline \multirow{2}{*}{ Treatment } & \multicolumn{3}{|c|}{ Green biomass accumulation/g per plant } & \multicolumn{3}{|c|}{ Dry biomass accumulation/g per plant } \\
\hline & $\mathrm{LW}_{\dagger}$ & $\mathrm{SW}_{\dagger}$ & Total & $\mathrm{LW}_{\dagger}^{\dagger}$ & $\mathrm{SW} \dagger$ & Total \\
\hline $\mathrm{W}_{1} \mathrm{~N}_{1} \mathrm{~K}_{1}$ & $173.0 \pm 12.4$ & $307.3 \pm 41.9$ & $480.4 \pm 54.4$ & $16.2 \pm 0.1$ & $24.1 \pm 1.5$ & $40.2 \pm 1.4$ \\
\hline $\mathrm{W}_{1} \mathrm{~N}_{2} \mathrm{~K}_{2}$ & $182.8 \pm 13.7$ & $276.2 \pm 22.7$ & $459.0 \pm 9.0$ & $15.2 \pm 1.7$ & $22.7 \pm 1.4$ & $37.9 \pm 0.3$ \\
\hline $\mathrm{W}_{1} \mathrm{~N}_{3} \mathrm{~K}_{3}$ & $200.8 \pm 0.5$ & $326.8 \pm 8.1$ & $527.7 \pm 8.6$ & $18.4 \pm 1.1$ & $26.8 \pm 1.2$ & $45.2 \pm 2.3$ \\
\hline $\mathrm{W}_{2} \mathrm{~N}_{1} \mathrm{~K}_{2}$ & $184.7 \pm 4.2$ & $345.4 \pm 0.3$ & $530.1 \pm 3.9$ & $15.4 \pm 2.1$ & $26.8 \pm 3.6$ & $42.2 \pm 1.5$ \\
\hline $\mathrm{W}_{2} \mathrm{~N}_{2} \mathrm{~K}_{3}$ & $234.4 \pm 9.9$ & $336.9 \pm 5.2$ & $571.3 \pm 4.8$ & $22.7 \pm 1.6$ & $28.9 \pm 0.1$ & $51.6 \pm 1.5$ \\
\hline $\mathrm{W}_{2} \mathrm{~N}_{3} \mathrm{~K}_{1}$ & $230.7 \pm 49.0$ & $334.0 \pm 3.8$ & $564.8 \pm 45.3$ & $24.2 \pm 6.4$ & $27.0 \pm 0.3$ & $51.2 \pm 6.1$ \\
\hline $\mathrm{W}_{3} \mathrm{~N}_{1} \mathrm{~K}_{3}$ & $190.5 \pm 4.6$ & $323.2 \pm 17.2$ & $513.8 \pm 21.7$ & $19.8 \pm 0.3$ & $28.7 \pm 3.7$ & $48.5 \pm 3.4$ \\
\hline $\mathrm{W}_{3} \mathrm{~N}_{2} \mathrm{~K}_{1}$ & $217.6 \pm 22.5$ & $354.8 \pm 0.1$ & $572.4 \pm 22.6$ & $21.0 \pm 1.8$ & $29.7 \pm 0.7$ & $50.7 \pm 1.1$ \\
\hline $\mathrm{W}_{3} \mathrm{~N}_{3} \mathrm{~K}_{2}$ & $219.7 \pm 39.5$ & $332.0 \pm 49.8$ & $551.8 \pm 89.3$ & $21.8 \pm 4.1$ & $31.1 \pm 1.8$ & $52.9 \pm 5.8$ \\
\hline $\mathrm{CK}$ & $164.3 \pm 18.6$ & $330.5 \pm 34.0$ & $494.8 \pm 15.4$ & $20.0 \pm 5.1$ & $32.6 \pm 2.3$ & $52.5 \pm 2.7$ \\
\hline Irrigation & ns & * & * & $*$ & $* * *$ & $* *$ \\
\hline Fertilizer, $\mathrm{N}$ & $* *$ & ns & ns & ns & $*$ & ns \\
\hline Fertilizer, K & $\mathrm{ns}$ & $\mathrm{ns}$ & $*$ & $\mathrm{~ns}$ & $\mathrm{~ns}$ & $*$ \\
\hline
\end{tabular}

Note: Mean value (g/plant) \pm Standard Error. †Leaf weight $(\mathrm{LW}), \quad$ Stem weight $(\mathrm{SW})$. ‘***'means $p<0.001$, ‘**’ means $0.001<p<0.01$ and ‘*’ means $0.01<p<0.05$, 'ns' means $p>0.05$.
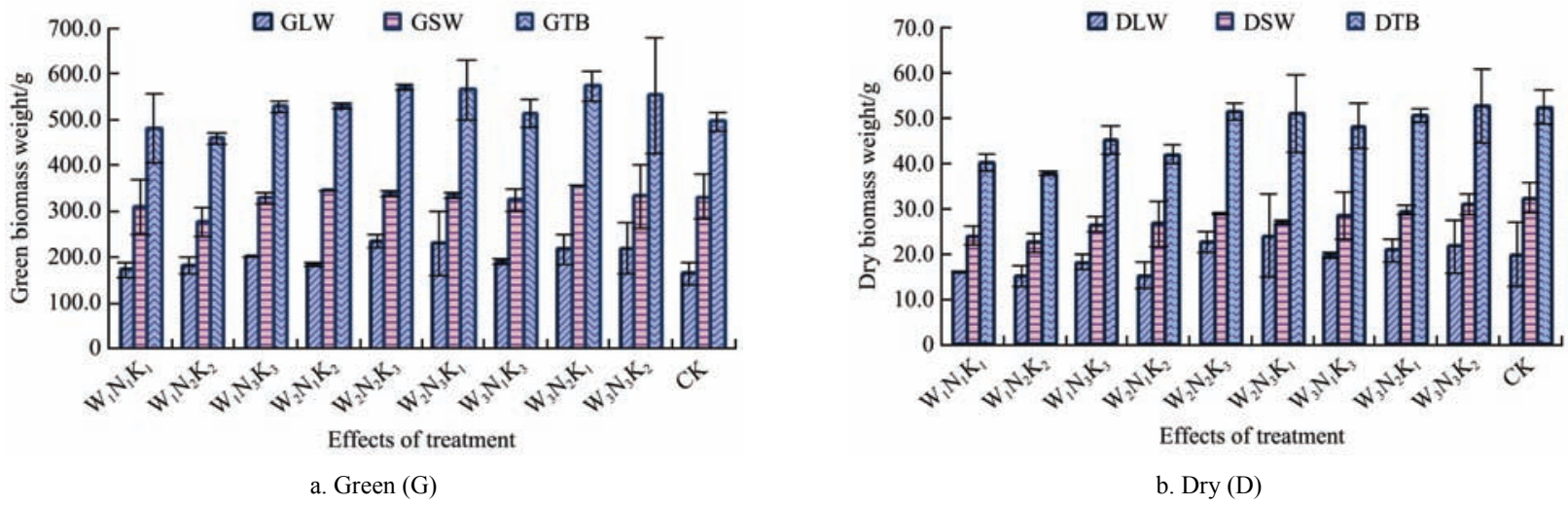

Note: Error bar represents the standard deviation.

Figure 4 Effects of treatments on cucumber biomass accumulation per plant; Leaf weight (LW), stem weight (SW), and total biomass (TB)

\subsection{Effects of treatments on cucumber yield}

The effects of treatments on cucumber yield are given in Table

2. The highest marketable cucumber yield was obtained at $129.99 \mathrm{t} / \mathrm{hm}^{2}$ with treatment $\mathrm{W}_{3} \mathrm{~N}_{2} \mathrm{~K}_{1}$, while the lowest yield was $113.29 \mathrm{t} / \mathrm{hm}^{2}$ with $\mathrm{W}_{1} \mathrm{~N}_{1} \mathrm{~K}_{1}$. The highest cucumber yield was $13 \%$ and $0.5 \%$ greater than lowest yield and CK yield $\left(129.35 \mathrm{t} / \mathrm{hm}^{2}\right)$ respectively and was also found $12 \%$ and $10 \%$ greater than average yield value of $\mathrm{W}_{1}, \mathrm{~W}_{2}$ group treatments respectively. It was indicated that the cucumber yield primarily increases with the increasing of water application. A relation between seasonal water application $(\mathrm{mm})$ and cucumber yield $\left(\mathrm{t} / \mathrm{hm}^{2}\right)$ indicated a closed linear fitting $\left(R^{2}=0.97\right)$ within this two parameters as shown in Figure 5a. Meanwhile, fertilizer has effect on cucumber yield also. The yield with $\mathrm{W}_{3} \mathrm{~N}_{2} \mathrm{~K}_{1}$ was $5 \%$ and $6 \%$ greater than same water applied treatment $\mathrm{W}_{3} \mathrm{~N}_{1} \mathrm{~K}_{3}$ and $\mathrm{W}_{3} \mathrm{~N}_{1} \mathrm{~K}_{3}$, respectively, due to effect of fertilizer combination. Moreover, irrigation and fertilizer interaction was more effective on cucumber yield, though deficit water was employed. It has been concluded by Alomran and Louki $^{[13]}$ that, deficit irrigation ( $80 \%$ of ETc) was more effective to good marketable yield and water saving compared with $100 \%$ of ETc. In this experiment, it was recognized that certain level of deficit water application combined with proper fertilization can get improved marketable yield. The highest yield of cucumber in this experiment was achieved by irrigation at $85 \%$ of field capacity with $\mathrm{N}_{2} \mathrm{~K}_{1}$ fertilizer combination. Statistical analysis indicated that the water and fertilizer (NK) application could significantly influence 
$(p<0.001)$ average cucumber yield. More specifically, the average cucumber yield for treatments $\mathrm{W}_{2} \mathrm{~N}_{1} \mathrm{~K}_{2}$ and $\mathrm{W}_{2} \mathrm{~N}_{3} \mathrm{~K}_{1}$ were significantly $(p<0.05)$ different from those for all other treatments as given in Table 2. Similar cucumber yield was reported by Ayas and Demirtaş ${ }^{[9]}$, that the highest yield was recorded at 148 $\mathrm{t} / \mathrm{hm}^{2}$ and $108 \mathrm{t} / \mathrm{hm}^{2}$ by $100 \%$ and $75 \%$ of Class A evaporation pan in greenhouse condition respectively. Alomran et al. ${ }^{[29]}$ reported highest cucumber yield of $150 \mathrm{t} / \mathrm{hm}^{2}$ under full irrigation greenhouse condition in arid region. Hakim and Chand ${ }^{[30]}$ reported maximum yield $\left(88.8 \mathrm{t} / \mathrm{hm}^{2}\right)$ obtained at $65 \%$ of ETc with
NPK fertilizer $\left(175: 125: 300 \mathrm{~kg} / \mathrm{hm}^{2}\right)$ application under natural ventilated greenhouse. Compare to these previous research results, it was revealed that greenhouse cucumber productions were improving in present study area.

On the other hand, greenhouse cucumber yield was always found higher than that of field grown cucumber, as highest field grown cucumber yield reported by Beyaert et al. ${ }^{[27]}\left(75.8 \mathrm{t} / \mathrm{hm}^{2}\right)$, Yaghi et al. ${ }^{[10]}\left(63.9 \mathrm{t} / \mathrm{hm}^{2}\right)$ and Ertek et al. ${ }^{[11]}\left(45.20 \mathrm{t} / \mathrm{hm}^{2}\right)$ are obviously lower than those reported highest greenhouse grown cucumber yield.

Table 2 Effects of irrigation and fertilizer combined treatments on yield, water use efficiency (WUE) and fruit physical quality of cucumber

\begin{tabular}{|c|c|c|c|c|c|c|c|c|c|c|c|c|}
\hline \multirow{2}{*}{ Treatment } & \multirow{2}{*}{$\begin{array}{c}E T_{a} \\
/ \mathrm{m}^{3} \cdot \mathrm{hm}^{-2}\end{array}$} & \multicolumn{3}{|c|}{ Fruit weight/g per fruit } & \multicolumn{3}{|c|}{ Fruit length/cm } & \multicolumn{3}{|c|}{ Fruit Diameter $/ \mathrm{mm}$} & \multirow{2}{*}{$\begin{array}{l}\text { Yield/ } \\
\mathrm{t} \cdot \mathrm{hm}^{-2}\end{array}$} & \multirow{2}{*}{$\begin{array}{l}\text { WUE/ } \\
\mathrm{kg} \cdot \mathrm{m}^{-3}\end{array}$} \\
\hline & & $122 \mathrm{D}$ & $127 \mathrm{D}$ & $134 \mathrm{D}$ & $122 \mathrm{D}$ & $127 \mathrm{D}$ & $134 \mathrm{D}$ & $122 \mathrm{D}$ & $127 \mathrm{D}$ & $134 \mathrm{D}$ & & \\
\hline $\mathrm{W}_{1} \mathrm{~N}_{1} \mathrm{~K}_{1}$ & 874.91 & $115.5 \pm 2.9^{\mathrm{a}}$ & $116.03 \pm 7.8^{\mathrm{a}}$ & $24.36 \pm 4.0^{\mathrm{a}}$ & $5.9 \pm 0.8^{\mathrm{a}}$ & $26.20 \pm 0.6^{\mathrm{a}}$ & $6.55 \pm 0.6^{\mathrm{a}}$ & $24.2 \pm 1.1^{\mathrm{a}}$ & $24.51 \pm 0.4^{\mathrm{a}}$ & $5.95 \pm 0.8^{\mathrm{a}}$ & $13.29 \pm 0.2^{\mathrm{a}}$ & $130.11 \pm 9.1^{\mathrm{h}}$ \\
\hline $\mathrm{W}_{1} \mathrm{~N}_{2} \mathrm{~K}_{2}$ & 924.15 & $145.6 \pm 21.9^{\mathrm{a}}$ & $133.37 \pm 5.6^{\mathrm{ab}}$ & $138.67 \pm 11.4^{\mathrm{a}}$ & $25.3 \pm 1.5^{\mathrm{a}}$ & $25.67 \pm 1.4^{\mathrm{a}}$ & $26.27 \pm 1.2^{\mathrm{a}}$ & $26.8 \pm 0.5^{\mathrm{ab}}$ & $25.23 \pm 0.9^{\mathrm{ab}}$ & $26.07 \pm 0.7^{\mathrm{a}}$ & $114.61 \pm 1.1^{\mathrm{c}}$ & $124.06 \pm 1.8^{\mathrm{g}}$ \\
\hline $\mathrm{W}_{1} \mathrm{~N}_{3} \mathrm{~K}_{3}$ & 852.97 & $127.5 \pm 6.5^{\mathrm{a}}$ & $134.20 \pm 6.1^{\mathrm{ab}}$ & $134.00 \pm 8.2^{\mathrm{a}}$ & $25.4 \pm 0.9^{\mathrm{a}}$ & $25.60 \pm 1.5^{\mathrm{a}}$ & $25.43 \pm 0.6^{\mathrm{a}}$ & $25.9 \pm 0.8^{\mathrm{ab}}$ & $26.74 \pm 0.5^{\mathrm{ab}}$ & $26.58 \pm 1.1^{\mathrm{a}}$ & $113.99 \pm 0.8^{b}$ & $133.82 \pm 4.5^{\mathrm{i}}$ \\
\hline $\mathrm{W}_{2} \mathrm{~N}_{1} \mathrm{~K}_{2}$ & 1035.19 & $125.8 \pm 12.6^{\mathrm{a}}$ & $135.43 \pm 9.8^{\mathrm{ab}}$ & $131.40 \pm 8.3^{\mathrm{a}}$ & $24.4 \pm 0.3^{\mathrm{a}}$ & $25.83 \pm 0.4^{\mathrm{a}}$ & $24.97 \pm 0.8^{\mathrm{a}}$ & $26.6 \pm 2.0^{\mathrm{ab}}$ & $27.68 \pm 1.3^{\mathrm{b}}$ & $26.82 \pm 0.5^{\mathrm{a}}$ & $117.03 \pm 1.9^{\mathrm{d}}$ & $113.11 \pm 2.8^{\mathrm{e}}$ \\
\hline $\mathrm{W}_{2} \mathrm{~N}_{2} \mathrm{~K}_{3}$ & 1093.23 & $115.7 \pm 3.9^{\mathrm{a}}$ & $115.33 \pm 8.7^{\mathrm{a}}$ & $126.33 \pm 13.4^{\mathrm{a}}$ & $23.1 \pm 0.5^{\mathrm{a}}$ & $24.47 \pm 0.9^{\mathrm{a}}$ & $25.47 \pm 0.7^{\mathrm{a}}$ & $26.5 \pm 0.7^{\mathrm{ab}}$ & $26.35 \pm 1.3^{\mathrm{ab}}$ & $26.99 \pm 0.9^{\mathrm{a}}$ & $118.28 \pm 1.6^{\mathrm{e}}$ & $108.22 \pm 1.1^{\mathrm{d}}$ \\
\hline $\mathrm{W}_{2} \mathrm{~N}_{3} \mathrm{~K}_{1}$ & 1017.49 & $124.1 \pm 24.6^{\mathrm{a}}$ & $132.47 \pm 18.2^{\mathrm{ab}}$ & $131.00 \pm 15.4^{\mathrm{a}}$ & $24.4 \pm 3.0^{\mathrm{a}}$ & $24.87 \pm 0.2^{\mathrm{a}}$ & $25.97 \pm 1.1^{\mathrm{a}}$ & $25.8 \pm 0.8^{\mathrm{ab}}$ & $25.76 \pm 1.0^{\mathrm{ab}}$ & $26.57 \pm 0.6^{\mathrm{a}}$ & $117.01 \pm 1.5^{\mathrm{d}}$ & $114.99 \pm 0.7^{\mathrm{f}}$ \\
\hline $\mathrm{W}_{3} \mathrm{~N}_{1} \mathrm{~K}_{3}$ & 1352.09 & $143.0 \pm 15.0^{\mathrm{a}}$ & $139.50 \pm 2.02^{\mathrm{ab}}$ & $142.33 \pm 3.8^{\mathrm{a}}$ & $25.0 \pm 1.5^{\mathrm{a}}$ & $25.90 \pm 1.7^{\mathrm{a}}$ & $26.20 \pm 0.2^{\mathrm{a}}$ & $28.3 \pm 0.8^{b}$ & $27.69 \pm 0.8^{\mathrm{b}}$ & $27.23 \pm 1.1^{\mathrm{a}}$ & $123.67 \pm 1.8^{\mathrm{g}}$ & $91.50 \pm 1.8^{\mathrm{c}}$ \\
\hline $\mathrm{W}_{3} \mathrm{~N}_{2} \mathrm{~K}_{1}$ & 1552.29 & $122.9 \pm 31.6^{\mathrm{a}}$ & $127.57 \pm 19.1^{\mathrm{ab}}$ & $126.53 \pm 15.9^{\mathrm{a}}$ & $22.6 \pm 1.1^{\mathrm{a}}$ & $25.40 \pm 0.4^{\mathrm{a}}$ & $25.10 \pm 1.7^{\mathrm{a}}$ & $27.8 \pm 2.0^{\mathrm{b}}$ & $27.92 \pm 0.6^{\mathrm{b}}$ & $27.83 \pm 0.6^{\mathrm{a}}$ & $129.99 \pm 0.8^{\mathrm{i}}$ & $83.76 \pm 1.3^{\mathrm{b}}$ \\
\hline $\mathrm{W}_{3} \mathrm{~N}_{3} \mathrm{~K}_{2}$ & 1331.39 & $103.7 \pm 12.9^{\mathrm{a}}$ & $112.80 \pm 5.6^{\mathrm{a}}$ & $122.57 \pm 16.7^{\mathrm{a}}$ & $22.9 \pm 0.8^{\mathrm{a}}$ & $24.97 \pm 0.6^{\mathrm{a}}$ & $24.27 \pm 1.1^{\mathrm{a}}$ & $24.6 \pm 0.5^{\mathrm{a}}$ & $26.64 \pm 1.1^{\mathrm{ab}}$ & $26.15 \pm 1.1^{\mathrm{a}}$ & $122.37 \pm 0.4^{\mathrm{f}}$ & $91.95 \pm 1.8^{\mathrm{c}}$ \\
\hline $\mathrm{CK}$ & 1723.64 & $149.9 \pm 6.0^{\mathrm{a}}$ & $149.70 \pm 2.4^{\mathrm{b}}$ & $136.40 \pm 16.4^{\mathrm{a}}$ & $25.5 \pm 0.4^{\mathrm{a}}$ & $25.47 \pm 0.4^{\mathrm{a}}$ & $25.10 \pm 0.6^{\mathrm{a}}$ & $27.3 \pm 0.8^{\mathrm{ab}}$ & $26.60 \pm 1.7^{\mathrm{ab}}$ & $26.47 \pm 1.1^{\mathrm{a}}$ & $129.35 \pm 2.1^{\mathrm{h}}$ & $75.14 \pm 2.25^{\mathrm{a}}$ \\
\hline Water & & ns & $*$ & ns & ns & ns & $*$ & $*$ & ** & ns & $* * *$ & $* * *$ \\
\hline $\mathrm{N}$ & & * & * & ns & * & ns & ns & ns & ns & ns & $* * *$ & $* * *$ \\
\hline K & & $*$ & ns & ns & $*$ & $*$ & ns & ns & $*$ & $*$ & $* * *$ & $* * *$ \\
\hline
\end{tabular}

Note: Mean \pm Standard deviation. D, day after transplanting. $E T_{a}$, seasonal water applied. Small letter within columns represents mean values are significantly different $(p=0.05)$ based on Tukey's-b test. ' '***'means $p<0.001$, '**' means $0.001<p<0.01$ and '*' means $0.01<p<0.05$, 'ns' means $p>0.05$.
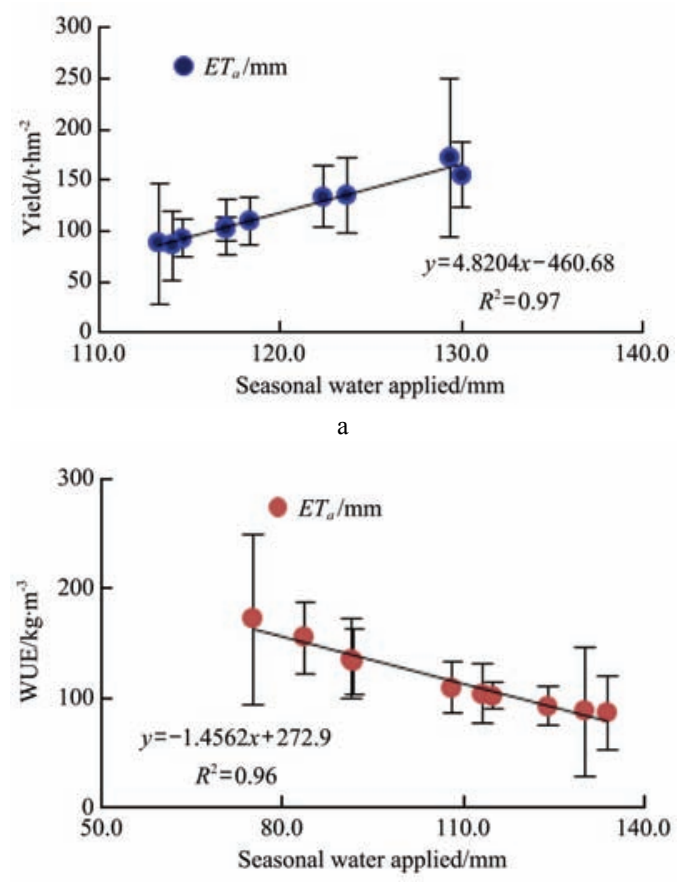

b

Note: Error bar represents the standard deviation.

Figure 5 Relationship between seasonal water application with (a) cucumber yield and (b) water use efficiency

\subsection{Water use and water use efficiency}

The total seasonal water applied $\left(E T_{a}\right)$ and water use efficiency (WUE) are given in Table 2. The total amount of seasonal water applied ranges from $852.97(85.3 \mathrm{~mm})$ to $1723.64 \mathrm{~m}^{3} / \mathrm{hm}^{2}$ $(172.36 \mathrm{~mm})$ for different level of treatment, in which negligible variation of estimation and application amount is explicitly given in Table 2. The relationship between seasonal water application $(\mathrm{mm})$ and WUE $\left(\mathrm{kg} / \mathrm{m}^{3}\right)$ represented a close linear relation $\left(R^{2}=0.96\right)$ as shown in Figure $5 \mathrm{~b}$. The highest value of WUE was obtained at $133.82 \mathrm{~kg} / \mathrm{m}^{3}$ with treatment $\mathrm{W}_{1} \mathrm{~N}_{3} \mathrm{~K}_{3}$, whereas the lowest value was obtained at $75.14 \mathrm{~kg} / \mathrm{m}^{3}$ with $\mathrm{CK}$. In other previous reports, Alomran and Louki ${ }^{[13]}$ and Zhang et al. ${ }^{[15]}$ reported that deficit irrigation leads to increase of WUE. Yaghi et al. ${ }^{[10]}$ reported highest WUE at $26.2 \mathrm{~kg} / \mathrm{m}^{3}$ in filed grown cucumber under plastic mulch drip irrigation, and Alomran et al. ${ }^{[29]}$ reported highest value of WUE in greenhouse cucumber at $61.9 \mathrm{~kg} / \mathrm{m}^{3}$ in water application at $40 \%$ of $E T_{c}$. In present research, the WUE value is little bit high because of lesser seasonal water applied $\left(E T_{a}\right)$ than control and almost no evaporation losses due to use of plastic film mulching. The WUE of $\mathrm{W}_{1}$ group treatments obtained remarkably high value because of water application in these treatments was $10 \%, 20 \%$ and $35 \%$ less than $\mathrm{W}_{2}, \mathrm{~W}_{3}$ groups and $\mathrm{CK}$, respectively. The result indicated that WUE increased by decreased application of water, which also corresponds to increasing marketable yield. Therefore, the water and fertilizer combination could efficiently improve the WUE, which is consistent with the previous study reported by Wang and Xing ${ }^{[8]}$.

The statistical analysis shows that irrigation and fertilization for all treatments could significantly $(p<0.001)$ affect WUE. Precisely, the WUE with treatments $\mathrm{W}_{3} \mathrm{~N}_{1} \mathrm{~K}_{3}$ and $\mathrm{W}_{3} \mathrm{~N}_{3} \mathrm{~K}_{2}$ were found significantly $(p=0.05)$ different from those of other 
treatments (Table 2).

The slope of water production function (WPF), named yield response factor $\left(K_{y}\right)$ for different treatments over entire cropping season, was calculated $\left(K_{y}=\left[1-\frac{Y_{a}}{Y_{m}}\right] /\left[1-\frac{E T_{a}}{E T_{m}}\right]\right)$ from the treatments of deficit water application. A close linear relation $\left(R^{2}=0.96\right)$ between the relative decrease of yield to the corresponding relative decrease in water application was discovered as shown in Figure 6 and calculated average $K_{y}$ value was 0.22 . The variation of $K_{y}$ value for different crops ranged widely from 0.2 to 1.15 according to $\mathrm{FAO}^{[23]}$, and ranged from 0.08 to 1.75 according to International Atomic Energy Agency (IAEA) $^{[31]}$. The $K_{y}$ value in this experiment was found consisted with these two reports which means the local variety of cucumber (Maria) grown in this experiment has more water deficit tolerant capacity under greenhouse condition in Northern China. Alomran et al. ${ }^{[29]}$ and Amer et al. ${ }^{[32]}$ reported $K_{y}$ value average 0.64 and 0.77 for greenhouse cucumber in Saudi Arabia and Northern Egypt climatic condition respectively. Therefore, the yield response factor $\left(K_{y}\right)$ could be vary depending on various climactic regions.

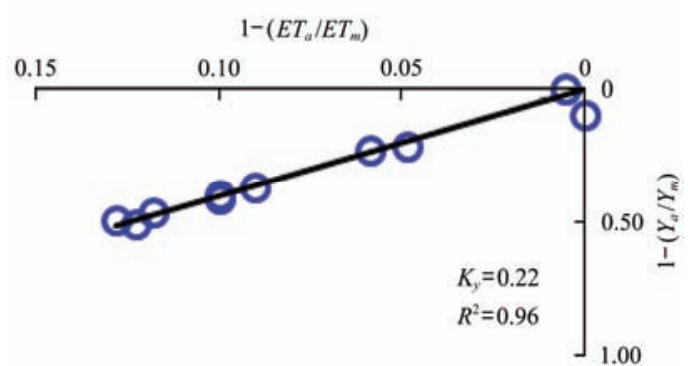

Figure 6 Relative decrease of cucumber yield corresponding to relative decrease in water application

\subsection{Effects of treatments on cucumber fruit physical quality}

The cucumber fruit physical quality (fruit weight, length and diameter) for all treatments at different harvesting date is given in Table 2 and also depicted in Figures 7a-7c. The highest value of fruit weight was $149.9 \mathrm{~g}$ /fruit with $\mathrm{CK}$ harvested $122 \mathrm{~d}$ after transplanting, while the lowest value was $103.5 \mathrm{~g} /$ fruit with $\mathrm{W}_{3} \mathrm{~N}_{3} \mathrm{~K}_{2}$ at the same harvesting time. Similar results were reported $134.67 \mathrm{~g} /$ fruit, $102.0 \mathrm{~g} /$ fruit, $136.5 \mathrm{~g} /$ fruit and $202.8 \mathrm{~g} /$ fruit from Arshad et al. ${ }^{[16]}$, Ayas and Demirtaş ${ }^{[9]}$, Ertek et al. ${ }^{[11]}$ and Zhang et al. ${ }^{[15]}$, respectively. The analysis shows that water application significantly $(p<0.05)$ influenced fruit weight harvested on 127 days after transplanting, while fertilizer $(\mathrm{N}, \mathrm{K})$ application significantly $(p<0.05)$ affect fruit weight harvested on $122 \mathrm{~d}$ after transplanting. It also shows that, the treatment set $\left\{\mathrm{W}_{1} \mathrm{~N}_{1} \mathrm{~K}_{1}\right.$, $\left.\mathrm{W}_{2} \mathrm{~N}_{2} \mathrm{~K}_{3}, \mathrm{~W}_{3} \mathrm{~N}_{3} \mathrm{~K}_{2}\right\}$ was significantly different from $\left\{\mathrm{W}_{1} \mathrm{~N}_{2} \mathrm{~K}_{2}\right.$ $\mathrm{W}_{1} \mathrm{~N}_{3} \mathrm{~K}_{3} \quad \mathrm{~W}_{2} \mathrm{~N}_{1} \mathrm{~K}_{2} \mathrm{~W}_{2} \mathrm{~N}_{3} \mathrm{~K}_{1} \quad \mathrm{~W}_{3} \mathrm{~N}_{1} \mathrm{~K}_{3} \quad \mathrm{~W}_{3} \mathrm{~N}_{2} \mathrm{~K}_{1}$ \} and $\mathrm{CK}$ harvested on $127 \mathrm{~d}$ after transplanting.

The highest value of fruit length was $26.55 \mathrm{~cm}$ with $\mathrm{W}_{1} \mathrm{~N}_{1} \mathrm{~K}_{1}$ harvested on $134 \mathrm{~d}$ after transplanting and the lowest value was $22.6 \mathrm{~cm}$ with $\mathrm{W}_{3} \mathrm{~N}_{2} \mathrm{~K}_{1}$ harvested on $122 \mathrm{~d}$ after transplanting. Average fruit length for all treatments was $25.1 \mathrm{~cm}$. Similar results of $18.18 \mathrm{~cm}$ and $15.2 \mathrm{~cm}$ were reported by Arshad et al. ${ }^{[16]}$ and Ertek et al. ${ }^{[11]}$ respectively. Statistical analysis indicated that the water application significantly $(p<0.05)$ influenced fruit length on harvested $134 \mathrm{~d}$ after transplanting. It was also revealed that fertilizer application also significantly $(p<0.05)$ influenced fruits length on 122 days after transplanting for urea and $122 \& 127$ days after transplanting for potash.
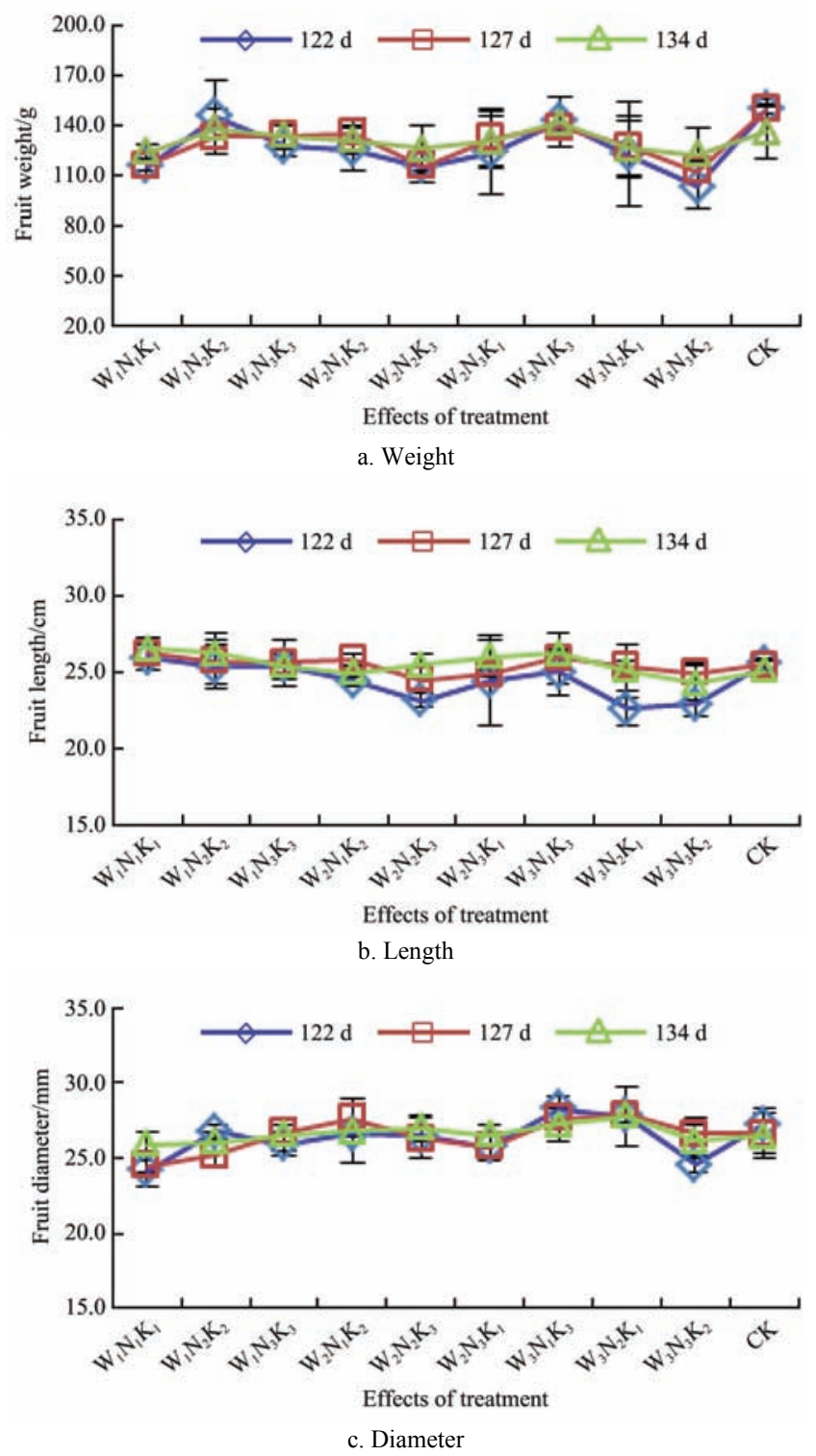

Note: Error bar represents the standard deviation. D denotes day after transplanting.

Figure 7 Effects of treatments on cucumber fruit physical quality

The highest fruit diameter was found $27.92 \mathrm{~mm}$ with $\mathrm{W}_{3} \mathrm{~N}_{2} \mathrm{~K}_{1}$ harvested on $127 \mathrm{~d}$ after transplanting, which is $13 \%$ greater than lowest value $(24.2 \mathrm{~mm})$ with $\mathrm{W}_{1} \mathrm{~N}_{1} \mathrm{~K}_{1}$ harvested on $122 \mathrm{~d}$ after transplanting and $4 \%$ greater than $\mathrm{CK}$ value $(26.79 \mathrm{~mm})$ (Table 2$)$. Relatively higher results were recorded as $40 \mathrm{~mm}$ and $37 \mathrm{~mm}$ reported by Ayas and Demirtaş ${ }^{[9]}$ and Ertek et al. ${ }^{[1]]}$ respectively. The water application significantly $(p<0.01)$ influenced fruit diameter except harvested on $134 \mathrm{~d}$ after transplanting. The urea application has no significant $(p>0.05)$ influence on fruit diameter, whereas potash application has significant $(p<0.05)$ influence for all treatments except $122 \mathrm{~d}$ after transplanting.

\section{Conclusions}

The cucumber yield under drip irrigation and fertilization was improved by significant reduction in water application, resulting $15 \%-35 \%$ of less water applied in different treatments compared to CK. The highest improved marketable yield $\left(\mathrm{W}_{3} \mathrm{~N}_{2} \mathrm{~K}_{1}\right.$, $\left.129.99 \mathrm{t} / \mathrm{hm}^{2}\right)$ was $14.7 \%$ and $0.5 \%$ greater than lowest $\left(\mathrm{W}_{1} \mathrm{~N}_{1} \mathrm{~K}_{1}\right.$, $\left.113.29 \mathrm{t} / \mathrm{hm}^{2}\right)$ and CK $\left(129.35 \mathrm{t} / \mathrm{hm}^{2}\right)$ yield. The WUE of $\mathrm{W}_{1}$ group treatments were found remarkably high because of the $35 \%$ less water application than CK. Both water and fertilizer 
application were found to significantly $(p<0.001)$ influence cucumber yield and WUE for all treatments. The water and potash $(\mathrm{K})$ application was found to significantly influence total green and dry biomass accumulation, whereas application of urea $(\mathrm{N})$ did not affect them. However, irrigation and fertilizer $(\mathrm{N}, \mathrm{K})$ treatments had significant $(p \leq 0.05)$ influence on cucumber fruit physical quality (weight, length and diameter) except certain date of measurement. At last, in response of drip water and fertilizer combined application, treatment $\mathrm{W}_{3} \mathrm{~N}_{2} \mathrm{~K}_{1}$ offered significant improved yield and increased WUE as well. Therefore, application of drip water at $85 \%$ of field capacity and fertilizer (N: $420 ; \mathrm{K}: 305, \mathrm{~kg} / \mathrm{hm}^{2}$ ) combination was successfully used in this study to improve cucumber marketable yield. This could be admissible to growers to sustain profitable yield, while reducing water application in lower water field capacity.

\section{[References]}

[1] Howell T A. Enhancing water use efficiency in irrigated agriculture. Agronomy journal, 2001; 93: 281-289.

[2] Phuntsho S, Shon H K, Hong S, Lee S, Vigneswaran S. A novel low energy fertilizer driven forward osmosis desalination for direct fertigation: Evaluating the performance of fertilizer draw solutions. Journal of Membrane Science, 2011; 375 (1-2): 172-181.

[3] Krüger E, Schmidt G, Brücker U. Scheduling strawberry irrigation based upon tensiometer measurement and a climatic water balance model. Scientia Horticulturae, 1999; 81(4): 409-424

[4] Martinez L, Thornsbury S, Nagai T. National and international factors in pickle markets. Agricultural Economics Report No. 628, Department of Agricultural Economics, Michigan State University, Oct 2006; 1-20.

[5] Chen J, Kang S, Du T, Qiu R, Guo P, Chen R. Quantitative response of greenhouse tomato yield and quality to water deficit at different growth stages. Agricultural Water Management, 2013; 129: 152-162.

[6] Li J, Zhang J, Ren L. Water and nitrogen distribution as affected by fertigation of ammonium nitrate from a point source. Irrigation Science, 2003; 22(1): 19-30.

[7] Wang Z, Liu Z, Zhang Z, Liu X. Subsurface drip irrigation scheduling for cucumber (Cucumis sativus L.) grown in solar greenhouse based on 20 $\mathrm{cm}$ standard pan evaporation in Northeast China. Scientia Horticulturae, 2009; 123(1): 51-57.

[8] Wang X K, Xing Y Y. Evaluation of the effect of irrigation and fertilization by drip fertigation on tomato yield and water use efficiency in greenhouse. International Journal of Agronomy, 2016; 1-10.

[9] Ayas S, Demirtaş Ç. Deficit irrigation effects on cucumber (Cucumis sativus L. Maraton) yield in unheated greenhouse condition. Journal of Food, Agriculture \& Environment, 2009; 7 (3-4): 645-649.

[10] Yaghi T, Arslana A, Naoum F. Cucumber (Cucumis sativus, L.) water use efficiency (WUE) under plastic mulch and drip irrigation. Agricultural Water Management, 2013; 128: 149-157.

[11] Ertek A, Sensoy S, Gedik I, Küçükyumuk C. Irrigation scheduling based on pan evaporation values for cucumber (Cucumis sativus L.) grown under field conditions. Agricultural Water Management, 2006; 81: 159-172.

[12] Hamza A A, Almasraf S A. Evaluation of the yield and water use efficiency of the cucumber inside greenhouses. J. of Babylon University Engineering Science, 2016; 24 (1): 95-106.

[13] Alomran A M, Louki I I. Yield response of cucumber to deficit irrigation in greenhouses. WIT Transactions on Ecology and the Environment,
Conference paper, Water Resources Management, 2011; 145(VI): 17-524.

[14] Buttaro D, Santamaria P, Signore A, Cantore V, Boari F, Montesano F F, et al. Irrigation management of greenhouse tomato and cucumber using tensiometer: Effects on yield, quality and water use. Agriculture and Agricultural Science Procedia, 2015; 4: 440-444.

[15] Zhang H, Chi D, Wang Q, Fang J, Fang X. Yield and quality response of cucumber to irrigation and nitrogen fertilization under subsurface drip irrigation in solar greenhouse. Agricultural Sciences in China, 2011; 10(6): 921-930.

[16] Arshad I, Ali W, Khan Z A. Effect of different levels of npk fertilizers on the growth and yield of greenhouse cucumber (Cucumis Sativus) by using drip irrigation technology. International Journal of Research, 2014; 1(8): 650-660

[17] Qi P S, Yong C, Tao L. Micro irrigation fertilizer application manuals for farmers. Edited by Qing H Z. Zhong Duo Agricultural Press. China, 2008; 42-49. (Chinese).

[18] Zotarelli L, Scholberg J M, Dukes M D, Muñoz-Carpena R, Icerman J. Tomato yield, biomass accumulation, root distribution and irrigation water use efficiency on a sandy soil, as affected by nitrogen rate and irrigation scheduling. Agricultural Water Management, 2009; 96(1): 23-34.

[19] Nong W Z, Nong L Y, Yi M X, Jie M Y, Wen W E, Xia W M, et al. Irrigation and Drainage Engineering. China Agricultural Press. $2^{\text {nd }}$ Edition. China, 2009. (Chinese).

[20] Israelsan O W, Hansen V E. Irrigation principles and practices, 3rd Ed. John Wily and Sons. New York, 1979.

[21] Mamun Hossain S A A, Wang L, Chen T, Li, Z. Leaf area index assessment for tomato and cucumber growing period under water treatments. J. of Plant, Soil and Environment, 2017; 63 (10): 461-467.

[22] FAO (Food and Agriculture Organization). Crop water requirements. In: Irrigation and Drainage, Paper No. 24. FAO, Rome, Italy, 1982.

[23] Lovelli S, Perniola M, Ferrara A, Tommaso T D. Yield response factor to water $(\mathrm{Ky})$ and water use efficiency of Carthamus tinctorius L. and Solanum melongena L. Agricultural Water Management, 2007; 92: 73-80.

[24] Doorenbos J, Kassam A H. Yield response factor to water. FAO Irrigation and Drainage paper no. 33. Rome, Italy, 1979.

[25] Steduto P, Hsiao T C, Fereres E, Raes D. 2012. Crop yield response to water. FAO Irrigation and Drainage, Paper No. 66. Rome, Italy, 2012.

[26] Tafteh A, Babazadeh H, EbrahimiPak N A, Kaveh F. Evaluation and Improvement of Crop Production Functions for Simulation Winter Wheat Yields with Two Types of Yield Response Factors. Journal of Agricultural Science, 2013; 5(3): 111-122.

[27] Beyaert R P, Roy R C, Ball-Coelh B R. Irrigation and fertilizer management effects on processing cucumber productivity and water use efficiency. Can. J. Plant Sci., 2006; 87: 355-363.

[28] Ghehsareh A M, Hematian M, Kalbasi M. Comparison of date-palm wastes and perlite as culture substrates on growing indices in greenhouse cucumber. Int. J. Recycl. Org. Waste Agricult., 2012; 1: 1-5.

[29] Alomran A M, Louki I I, Aly A A, Nadeem M E. Impact of deficit irrigation on soil salinity and cucumber yield under greenhouse condition in an arid environment. J. Agr. Sci. Tech., 2013; 15: 1247-1259.

[30] Hakim V M A, Chand A R J. Effect of drip irrigation levels on yield of salad cucumber under naturally ventilated polyhouse. IOSR Journal of Engineering, 2014; 4(4): 18-21.

[31] Moutonnet P. Yield Response to field crops to deficit irrigation. In: "Deficit Irrigation Practices", (Eds.): Kirda C, Moutonnet P, Hera C, Nielsen D R. Water Report No.22, FAO, Rome, 2000; pp.11-16.

[32] Amer K H, Midan S A, Hatfield J L. Effect of deficit irrigation and fertilization on cucumber. Agronomy Journal, 2009; 101(6): 1556-1564. 